\title{
Autoimmune Hepatitis-Primary Biliary Cholangitis Overlap Syndrome Triggered by COVID-19
}

\author{
Balraj Singh ${ }^{1}$, Parminder Kaur ${ }^{2}$, Michael Maroules ${ }^{1}$ \\ ${ }^{1}$ Department of Hematology \& Oncology, Saint Joseph's University Medical Center, Paterson, NJ, USA \\ ${ }^{2}$ Department of Cardiology, Saint Joseph's University Medical Center, Paterson, NJ, USA
}

Received: 03/01/2021

Accepted: 08/01/2021

Published: 04/02/2021

How to cite this article: Singh B, Kaur P, Maroules M. Autoimmune hepatitis - primary biliary cholangitis overlap syndrome triggered by COVID-19. EJCRIM 2021;8: doi:10.12890/2021_002264.

Conflicts of Interests: The Authors declare that there are no competing interests.

This article is licensed under a Commons Attribution Non-Commercial 4.0 License

\section{ABSTRACT}

COVID-19, caused by severe acute respiratory syndrome coronavirus 2 infection, has caused the ongoing global pandemic. Initially considered a respiratory disease, it can manifest with a wide range of complications (gastrointestinal, neurological, thromboembolic and cardiovascular) leading to multiple organ dysfunction. A range of immune complications have also been described. We report the case of a 57-year-old man with a medical history of hypertension, prediabetes and beta thalassemia minor, who was diagnosed with COVID-19 and subsequently developed fatigue and arthralgias, and whose blood work showed hyperferritinemia, elevated liver enzymes (AST/ALT/GGT), hypergammaglobulinemia, anti-smooth muscle antibody, anti-mitochondrial antibody, and anti-double-stranded DNA antibodies. The patient was diagnosed with autoimmune hepatitis-primary biliary cholangitis overlap syndrome triggered by COVID-19. To our knowledge, this is the first such case reported.

\section{LEARNING POINTS}

- COVID-19 can precipitate a wide range of immune complications; we report a case of autoimmune hepatitis-primary biliary cholangitis overlap syndrome triggered by COVID-19.

- Clinicians should be aware of this unusual manifestation of COVID-19 so that prompt and appropriate diagnostic and therapeutic interventions can be initiated if the syndrome is suspected or confirmed.

- Our case further suggests the necessity for continued and regular follow-up of patients who have recovered from COVID-19 in order to uncover the long-term effects of the novel virus.

\section{KEYWORDS}

Arthritis, autoimmune disease, COVID-19, SARS-CoV-2, autoimmune hepatitis, AlH, primary biliary cirrhosis, primary biliary cholangitis, overlap syndrome

\section{INTRODUCTION}

A novel coronavirus disease (COVID-19) pandemic, caused by severe acute respiratory syndrome coronavirus 2 (SARS-CoV-2), has affected millions of people worldwide since its emergence. Initially considered a respiratory tract pathogen, the virus can cause multiple organ dysfunction. Patients with COVID-19 may present with a range of immune complications including Guillain-Barré syndrome, Miller Fisher syndrome, antiphospholipid syndrome, immune thrombocytopenic purpura, systemic lupus erythematosus, Kawasaki disease, cold agglutinin disease and autoimmune haemolytic anaemia, neuromyelitis optica, NMDA-receptor encephalitis, myasthenia gravis, type I diabetes, large vessel vasculitis and thrombosis, psoriasis, subacute thyroiditis, Graves' disease, sarcoidosis and inflammatory arthritis ${ }^{[1]}$. Herein, we report the first case of autoimmune hepatitis (AIH)-primary biliary cholangitis (PBC) overlap syndrome triggered by COVID-19. 


\section{CASE DESCRIPTION}

We report the case of a 57-year-old man with a medical history of hypertension, prediabetes and beta thalassemia minor, who was diagnosed with COVID-19 in April 2020. The patient developed shortness of breath and cough and was diagnosed with COVID-19 by nasopharyngeal swab RT-PCR. He was quarantined at home for 2 weeks. The patient's respiratory symptoms resolved, but in May 2020, he started to feel fatigued and developed multiple joint pain involving the hand, wrist, knee and shoulder. The pain got progressively worse. He had not experienced nausea, vomiting, abdominal pain, itching, rash, bleeding from the nose or mouth, or blood in stools, and there was no history of alcohol or drug abuse, blood transfusions or iron supplementation. He was taking losartan, hydrochlorothiazide, fenofibrate and metformin at home. Laboratory test results are given in Table 1. The hepatitis panel including hepatitis A IgM antibodies (HA Ab-lgM), hepatitis B surface antigen ( $\mathrm{HBsAg}$ ), hepatitis B IgM core antibody (HBcAb-lgM), and hepatitis C antibodies (HC Ab) was negative, HIV was negative and body mass index was $25 \mathrm{~kg} / \mathrm{m}^{2}$. Ultrasound of the abdomen showed a normal sized liver with mild heterogeneous parenchyma and a slightly lobulated contour. There was a $12 \mathrm{~mm}$ cyst in the right hepatic lobe posteriorly. There was no evidence of intra-hepatic biliary ductal dilatation and the common bile duct diameter was $6 \mathrm{~mm}$. Blood flow in the main portal vein was hepatopetal. There was no evidence of gallstones. Endoscopy showed gastritis and colonoscopy showed internal haemorrhoids. Other work-up including anticentromere B antibodies, antichromatin antibodies, anti-Jo-1, anti-RNP antibodies, anti-scleroderma 70 antibodies, Smith antibodies, Sjogren anti-SS-A and Sjogren anti-SS-B was negative. Our patient was taking fenofibrate which has been associated with AlH, but he had been taking it for more than 3 years ${ }^{[2]}$. The patient was diagnosed with AlH-PBC overlap syndrome triggered by COVID-19 (given the sequence of events with COVID-19 infection followed by the onset of fatigue/arthralgias, laboratory evidence of hyperferritinemia, elevated liver enzymes (AST/ALT/GGT), hypergammaglobulinemia, anti-smooth muscle antibody, anti-mitochondrial antibody and anti-double-stranded DNA antibodies). Liver biopsy was not performed in view of the clinical presentation and serological evidence. The patient was started on ursodeoxycholic acid and continues to be followed up.

\section{DISCUSSION}

Autoimmune hepatitis is an immune-mediated, chronic, inflammatory disease of the liver is characterized by circulating autoantibodies, hypergammaglobulinemia and distinctive features on liver biopsy ${ }^{[3]}$. AlH has a wide spectrum of clinical presentation and can vary from asymptomatic disease to liver failure. PBC is a chronic, cholestatic, autoimmune disease with a variable progressive course. Patients with PBC may be asymptomatic, or they may present with signs and symptoms such as fatigue, pruritus, jaundice, cholestatic liver enzymes, antimitochondrial antibodies, and cirrhosis-related complications ${ }^{[4]}$.

The term 'overlap syndrome' is used to describe variant forms of AlH which present with characteristics of AlH and PBC or primary sclerosing cholangitis (PSC). AlH-PBC overlap syndrome is diagnosed when two or three criteria for PBC and AlH are fulfilled. AlH is diagnosed when two out of the following three criteria are present: (a) alanine aminotransferase (ALT) levels $>5 \times U L N$, (b) serum immunoglobulin G (lgG) levels $>2 \times$ ULN or a positive test for anti-smooth muscle antibodies (ASMA), and (c) liver biopsy specimen showing moderate or severe periportal or periseptal lymphocytic piecemeal necrosis. PBC is diagnosed when two out of the following three criteria are present: (a) alkaline phosphatase (AP) levels $>2 \times$ ULN or $y$-glutamyl transpeptidase (GGT) levels $>5 \times U L N$, (b) a positive test for antimitochondrial antibodies (AMA), and (c) liver biopsy specimen showing florid bile duct lesions ${ }^{[5]}$. Our patient met $2 / 3$ criteria for each of AlH and PBC, although a liver biopsy was not done. Furthermore, previous reports have suggested that concomitant AMA/anti-dsDNA seropositivity can be considered the serological profile of AlH-PBC overlap syndrome as in our case ${ }^{[6]}$.

The exact mechanisms leading to AlH-PBC overlap syndrome are not fully understood. In genetically predisposed individuals, viruses and drugs have been suggested as triggering agents for the autoimmune disease ${ }^{[2]}$. We report a case of AlH-PBC overlap syndrome triggered by COVID-19. Possible mechanisms include dysregulated and excessive immune responses to COVID-19 infection leading to cytokine storm and hyperferritinemia, molecular mimicry phenomena between pathogenic viruses and human proteins, and production of autoantibodies ${ }^{[1]}$. Our patient had elevated inflammatory markers (ferritin $3,275 \mathrm{ng} / \mathrm{ml}$ and ESR $66 \mathrm{~mm} / \mathrm{hr}$ ) suggesting an excessive immune response triggering autoimmune disease.

Clinicians should be aware of this unusual manifestation of COVID-19 so that prompt and appropriate diagnostic and therapeutic interventions can be initiated if the virus is suspected or confirmed. Our case further suggests the necessity for continued and regular follow-up of patients who have recovered from COVID-19 in order to uncover the long-term effects of the novel virus. 


\begin{tabular}{|c|c|c|}
\hline Test & Value & Reference Range \\
\hline Haemoglobin & $9.8 \mathrm{~g} / \mathrm{dl}$ & $13-17.7 \mathrm{~g} / \mathrm{dl}$ \\
\hline Haematocrit & $32.4 \%$ & $37.5-51 \%$ \\
\hline Red blood cells & $4.99 \times 106 / \mu l$ & $4.14-5.8 \times 106 / \mu l$ \\
\hline White blood cells & $8.1 \times 103 / \mu l$ & $3.4-10.8 \times 103 / \mu \mathrm{l}$ \\
\hline Platelets & $307 \times 103 / \mu l$ & $150-450 \times 103 / \mu l$ \\
\hline Mean corpuscular volume & $65 \mathrm{fl}$ & $79-97 f l$ \\
\hline Red cell distribution width & $18.7 \%$ & $11.6-15.4 \%$ \\
\hline Sodium & $136 \mathrm{mEq} / \mathrm{l}$ & $134-144 \mathrm{mEq} / \mathrm{l}$ \\
\hline Potassium & $4.5 \mathrm{mEq} / \mathrm{l}$ & $3.5-5.2 \mathrm{mEq} / \mathrm{l}$ \\
\hline Chloride & $98 \mathrm{mEq} / \mathrm{l}$ & $96-106 \mathrm{mEq} / \mathrm{l}$ \\
\hline Bicarbonate & $23 \mathrm{mEq} / \mathrm{l}$ & $20-29 \mathrm{mEq} / \mathrm{l}$ \\
\hline Blood glucose & $93 \mathrm{mg} / \mathrm{dl}$ & $65-99 \mathrm{mg} / \mathrm{dl}$ \\
\hline Blood urea nitrogen & $18 \mathrm{mg} / \mathrm{dl}$ & $6-24 \mathrm{mg} / \mathrm{dl}$ \\
\hline Creatinine & $0.91 \mathrm{mg} / \mathrm{dl}$ & $0.76-1.27 \mathrm{mg} / \mathrm{dl}$ \\
\hline Calcium & $9.4 \mathrm{mg} / \mathrm{dl}$ & $8.7-10.2 \mathrm{mg} / \mathrm{dl}$ \\
\hline Total protein & $8.8 \mathrm{~g} / \mathrm{dl}$, repeat $9.3 \mathrm{~g} / \mathrm{dl}$ & $6-8.5 \mathrm{~g} / \mathrm{dl}$ \\
\hline Albumin & $4.3 \mathrm{~g} / \mathrm{dl}$ & $3.8-4.9 \mathrm{~g} / \mathrm{dl}$ \\
\hline Globulin total & $4.5 \mathrm{~g} / \mathrm{dl}$, repeat $5 \mathrm{~g} / \mathrm{dl}$ & $1.5-4.5 \mathrm{~g} / \mathrm{dl}$ \\
\hline Gamma globulin & $3.8 \mathrm{~g} / \mathrm{dl}$ & $0.4-1.8 \mathrm{~g} / \mathrm{dl}$ \\
\hline M-spike & Not observed & Not observed \\
\hline $\lg G$ & $4,049 \mathrm{mg} / \mathrm{dl}$ & $603-1,613 \mathrm{mg} / \mathrm{dl}$ \\
\hline $\lg M$ & $281 \mathrm{mg} / \mathrm{dl}$ & $20-172 \mathrm{mg} / \mathrm{dl}$ \\
\hline $\lg A$ & $229 \mathrm{mg} / \mathrm{dl}$ & $90-386 \mathrm{mg} / \mathrm{dl}$ \\
\hline Bilirubin, total & $1 \mathrm{mg} / \mathrm{dl}$, repeat $2.1 \mathrm{mg} / \mathrm{dl}$ & $0-1.2 \mathrm{mg} / \mathrm{dl}$ \\
\hline Alkaline phosphatase & $48 \mathrm{U} / \mathrm{l}$, repeat $29 \mathrm{U} / \mathrm{I}$ & $39-117 \mathrm{U} / \mathrm{I}$ \\
\hline Aspartate aminotransferase & $137 \mathrm{U} / \mathrm{l}$, repeat $371 \mathrm{U} / \mathrm{I}$ & $0-40 \mathrm{U} / \mathrm{I}$ \\
\hline Alanine aminotransferase & $106 \mathrm{U} / \mathrm{I}$, repeat $246 \mathrm{U} / \mathrm{I}$ & $0-44 \mathrm{U} / \mathrm{I}$ \\
\hline Gamma-glutamyl transferase & $655 \mathrm{U} / \mathrm{I}$ & $0-65 \mathrm{U} / \mathrm{I}$ \\
\hline Prothrombin time & 10.4 seconds & $9.1-12$ seconds \\
\hline International Normalized Ratio & 1 & $0.8-1.2$ \\
\hline Partial thromboplastin time & 28 seconds & $24-33$ seconds \\
\hline Total iron binding capacity & $271 \mu \mathrm{g} / d \mathrm{l}$ & $250-450 \mu \mathrm{g} / \mathrm{dl}$ \\
\hline Iron & $222 \mu \mathrm{g} / d \mathrm{l}$ & $38-169 \mu \mathrm{g} / \mathrm{dl}$ \\
\hline Iron saturation & $82 \%$ & $15-55 \%$ \\
\hline Ferritin & $860 \mathrm{ng} / \mathrm{ml}$, repeat $3,275 \mathrm{ng} / \mathrm{ml}$ & $30-400 \mathrm{ng} / \mathrm{ml}$ \\
\hline Erythrocyte sedimentation rate & $66 \mathrm{~mm} / \mathrm{hr}$ & $0-30 \mathrm{~mm} / \mathrm{hr}$ \\
\hline Haemoglobin A1c & $5.9 \%$ & $4.8-5.6$ \\
\hline Anti-smooth muscle antibodies & 83 units & Positive $>30$ units \\
\hline Anti-mitochondrial antibodies & 174.5 units & Positive $>24.9$ units \\
\hline Anti-double-stranded DNA antibodies & $14 \mathrm{IU} / \mathrm{ml}$ & Positive $>9 \mathrm{IU} / \mathrm{ml}$ \\
\hline Anti-soluble liver antigen antibodies & 4.4 units & Negative $0-20$ units \\
\hline Anti-liver-kidney microsomal antibodies & $<20.1$ units & Negative $0-20$ units \\
\hline Antinuclear antibodies & Negative & Negative \\
\hline Atypical P-ANCA & Negative & Negative \\
\hline
\end{tabular}

Table 1. Laboratory test results 


\section{REFERENCES}

1. Halpert G, Shoenfeld Y. SARS-CoV-2, the autoimmune virus. Autoimmun Rev 2020;19(12):102695.

2. Rahim MN, Miquel R, Heneghan MA. Approach to the patient with acute severe autoimmune hepatitis. JHEP Rep 2020;2(6):100149.

3. Tanaka A. Autoimmune hepatitis: 2019 update. Gut Liver 2020;14(4):430-438.

4. Onofrio FQ, Hirschfield GM, Gulamhusein AF. A practical review of primary biliary cholangitis for the gastroenterologist. Gastroenterol Hepatol (N Y) 2019:15(3):145-154.

5. Rust C, Beuers U. Overlap syndromes among autoimmune liver diseases. World J Gastroenterol 2008;14(21):3368-3373.

6. Muratori P, Granito A, Pappas G, Pendino GM, Quarneti C, Cicola R, et al. The serological profile of the autoimmune hepatitis/primary biliary cirrhosis overlap syndrome. Am J Gastroenterol 2009;104(6):1420-1425. 